\title{
Penerapan Model Pembelajaran Berbasis Masalah Untuk Meningkatkan Aktivitas dan Hasil Belajar IPA Peserta Didik SMP
}

\author{
Ni Kedek Indri Wahyuni ${ }^{1}{ }^{*}$, Muhammad Anas ${ }^{2)}$, Luh Sukariasih ${ }^{3)}$ \\ 1)*Mahasiswa Pendidikan Fisika Universitas Halu Oleo \\ ${ }^{2), 3)}$ Dosen Pendidikan Fisika Universitas Halu Oleo
}

*Korespondensi Email: nikadekindriwahyuni@gmail.com

\begin{abstract}
Abstrak: Penelitian ini bertujuan untuk yaitu mendeskripsikan aktivitas belajar, hasil belajar, dan ketuntasan hasil belajar IPA peserta didik kelas VIII $_{C}$ SMPN 1 Uepai yang diajarkan menggunakan model pembelajaran berbasis masalah. Jenis penelitian ini adalah PTK yang telah dilaksanakan dalam II siklus. Subjek dalam penelitian ini adalah seluruh peserta didik semester genap tahun ajaran 2018/2019. Data penelitian dianalisis secara statistik deskriptif. Hasil analisis data: 1) aktivitas peserta didik setiap siklus rerata pada siklus I sebesar 2,4 dengan kategori cukup meningkat pada siklus II yaitu 3 dengan kategori baik; 2) hasil belajar peserta didik kelas VIII $_{C}$ pada siklus I diperoleh nilai 27,3 sampai dengan 100 dengan nilai rata-rata 70,5 dan standar deviasi 15,4, pada siklus II diperoleh nilai dari 55 sampai dengan 95 dengan nilai rata-rata 76,1 dan standar deviasi 10,1; dan 3) ketuntasan belajar fisika peserta didik mengalamai peningkatan pada siklus I sebesar $76,9 \%$ meningkat menjadi $83,3 \%$ pada siklus II.
\end{abstract}

Kata kunci: Model PBM; Aktivitas peserta didik; Hasil belajar peserta didik.

Abstract: This study aims to describe the learning activities, learning outcomes, and completeness of the science learning outcomes of class VIIIC students of SMPN 1 Uepai who are taught using a problem-based learning model. This type of research is the PTK which has been carried out in II cycles. The subjects in this study were all even semester students of the 2018/2019 academic year. The research data were analyzed using descriptive statistics. The results of data analysis: 1) the average activity of students in each cycle in the first cycle was 2.4 with a sufficiently increased category in the second cycle, namely 3 in the good category; 2) the learning outcomes of class VIIIC students in the first cycle obtained values of 27.3 to 100 with an average value of 70.5 and a standard deviation of 15.4, in the second cycle the values were obtained from 55 to 95 with an average value of 76,1 and standard deviation of 10,1; and 3) students' completeness in learning physics experienced an increase in the first cycle of $76.9 \%$, increasing to $83.3 \%$ in the second cycle.

Keywords: PBM Model; Student Activities; student learning outcomes.

\section{PENDAHULUAN}

Berdasarkan hasil wawancara kepada guru mata pelajaran IPA di SMP Negeri 1 Uepai pada tanggal 16 Oktober 2018, memperoleh informasi keaktifan peserta didik dan hasil belajar fisika. Di sekolah tersebut telah menerapkan sistem pembelajaran Kurikulum 2013, namun dalam pelaksanaan kurikulum 2013 belum optimal. Hal ini dikarenakan pendidik tidak dapat memaksimalkan alokasi waktu pembelajaran yang terdapat dalam Kurikukulum 2013. Dalam proses pembelajaran aktivitas pembelajaran di dalam kelas masih didominasi oleh guru, peserta didik hanya menerima pengetahuan yang diajarkan oleh pendidik, peserta didik kurang mendengarkan ketika pendidik menjelaskan materi serta tidak pernah melakukan kegiatan eksperimen. Aktivitas yang mereka lakukan di dalam ruang kelas yaitu menulis dan membaca ketika pendidik mengarahkan untuk menulis dan membaca. Sedangkan hasil belajar peserta didik kelas VIII $_{C}$ SMPN 1 Uepai masih rendah dibandingkan kelas lain. Dimana 11 orang atau 34\% peserta didik belum mencapai standar KKM dan 21 orang atau $66 \%$ peserta didik yang mencapai KKM yang ditetapkan oleh sekolah yaitu 70. Sementara nilai ulangan harian pada materi Cahaya dan Alat Optik pada tahun ajaran 2017/2018 peserta didik kelas VIII $_{C}$ tidak ada yang memenuhi KKM dan nilai rata-rata IPA pada tahun ajaran 2016/2017 yaitu 67,42. Dengan demikian, diperlukan suatu solusi sebagai 
alternatif tindakan dalam rangka mengatasi masalah tersebut.

Rendahnya hasil belajar peserta didik kelas VIII $_{C}$ SMPN 1 Uepai berdasarkan hasil wawancara terhadap pendidik fisika disebabkan oleh beberapa faktor yaitu pendidik belum memahami model pembelajaran kurikulum 2013, kurikulum 2013 sementara dalam tahap percobaan untuk pendidik sendiri, pembelajaran tidak sesuai dengan rencana pelaksanaan pembelajaran (RPP) yang telah dibuat, laboratorium sebagai salah satu sarana penunjang pembelajaran tidak digunakan, peserta didik tidak bertanya ketika materi yang diajarkan belum di pahami, sebagian besar peserta didik menyatakan tidak suka dengan pelajaran fisika serta kurangnya motivasi peserta didik untuk belajar. Cahaya dan Alat Optik merupakan fenomena yang sering kita temui dan pengamplikasiannya yang banyak dalam kehidupan sehari-hari. Di dalamnya memuat berbagai konsep diantaranya adalah sifat-sifat cahaya, pembentukan bayangan pada cermin dan lensa serta proses pembentukkan pada mata manusia. Konsep-konsep ini akan mudah dipahami dan dimengerti oleh peserta didik jika disajikan dalam bentuk permasalahan yang berhubungan dengan dunia nyata peserta didik. Kenyataannya, peserta didik di SMPN 1 Uepai belum bisa memahami materi cahaya dan alat optik dengan baik. Permasalahan ini tentu dapat diatasi dimana pendidik dan peneliti secara bersama-sama menentukan alternatif pemecahannya dengan memilih model pembelajaran yang tepat yaitu model pembelajaran berbasis masalah (PBM).

Nurhadi dalam (Fitriani 2015) mengatakan bahwa model pembelajaran berbasis masalah (PBM) adalah suatu model pembelajaran yang menggunakan masalah dunia nyata sebagai suatu konteks bagi siswa untuk belajar tentang cara berpikir kritis dan keterampilan pemecahan masalah, serta untuk memperoleh pengetahuan dan konsep esensial dari materi pelajaran. Model PBM juga dapat mendorong peserta didik untuk aktif dalam memperoleh pengetahuan dengan harapan dapat menimbulkan rasa senang, antusias peserta didik dalam belajar serta dapat menambah dan memperkuat pengetahuannya. Keberhasilan penerapan model pembelajaran berbasis masalah (PBM) dalam pembelajaran IPA dapat dilihat dalam penelitian Merinda Dian Prametasari (2012) yaitu model pembelajaran berbasis masalah dapat meningkatkan hasil belajar dan pembelajaran di kelas, sementara Nur Rahma Fitriani (2015) yaitu model pembelajaran berbasis masalah mampu meningkatkan keterampilan berpikir tingkat tinggi peserta didik dan penelitian yang dilakukan oleh Ardian Firmansyah (2015) yaitu pembelajaran berupa model pembelajaran berbasis masalah dengan metode eksperimen lebih meningkatkan kemampuan kognitif siswa daripada pembelajaran kovensional.

Berdasarkan fakta-fakta tersebut maka penulis tertarik untuk melakukan penelitian dengan judul Penerapan Model Pembelajaran Berbasis Masalah untuk Meningkatkan Aktivitas dan Hasil Belajar IPA Peserta Didik Kelas VIII ${ }_{C}$ SMPN 1 Uepai pada Materi Cahaya dan Optik.

\section{METODE}

Penelitian ini termasuk penelitian tindakan kelas (PTK) dengan menggunakan model pembelajaran berbasis masalah sebagai alternatif tindakan untuk meningkatkan aktivitas dan hasil belajar IPA peserta didik kelas VIII $_{C}$ SMP Negeri 1 Uepai dalam pembelajaran IPA pada materi Cahaya dan Alat Optik.

Penelitian ini mulai dilaksanakan pada tanggal 26 Maret 2019 semester genap tahun pelajaran 2018/2019 di SMP Negeri 1 Uepai. Subyek dalam penelitian ini adalah guru kelas VIII dan peserta didik kelas VIII SMP Negeri 1 Uepai 2018/2019 yang berjumlah 32 orang yang terdiri dari 16 orang laki-laki dan 16 orang perempuan. Penetapan kelas VIII $_{\mathrm{C}}$ didasarkan pada observasi awal pada tanggal 16 Oktober 2018 di SMP Negeri 1 Uepai.

Adapun pelaksaannya tindakan tersebut mengikuti prosedur penelitian tindakan kelas yaitu perencanaan (planning), tindakan (acting), pengamatan (observing) dan refleksi (reflecting) pada setiap siklus

\section{HASIL PENELITIAN \\ Data Aktivitas Peserta Didik}

Data aktivitas peserta didik pada kelas VIII $_{C}$ SMP Negeri 1 Uepai selama proses pembelajaran berlangsung melalui penerapan model pembelajaran berbasis masalah diperoleh dengan mengunakan lembar observasi dengan cara pemberian skor pada setiap aspek aktivitas peserta didik sesuai dengan kriteria yang telah ditentukan. Data mengenai distribusi rata-rata persatuan aktivitas peserta didik pada setiap siklus dapat dilihat pada Tabel 1 . 
Tabel 1. Rata-rata Persatuan Aktivitas Peserta Didik pada Setiap Siklus

\begin{tabular}{|c|c|c|c|c|c|}
\hline \multirow{2}{*}{ No. } & \multirow{2}{*}{ Aktivitas yang Diamati } & \multicolumn{2}{|c|}{ Siklus I } & \multicolumn{2}{|c|}{ Siklus II } \\
\hline & & Rata- rata & Kat. & Rata-rata & Kat. \\
\hline 1. & $\begin{array}{l}\text { Peserta didik mendengarkan dan } \\
\text { memperhatikan guru dengan baik secara } \\
\text { seksama dalam membuka pelajaran }\end{array}$ & 2,1 & $\mathrm{C}$ & 2,6 & $\mathrm{C}$ \\
\hline 2. & $\begin{array}{l}\text { Peserta didik merespon atau menanggapi } \\
\text { pertanyaan dari guru (bentuk interaksi) }\end{array}$ & 2,5 & $\mathrm{C}$ & 2,9 & $\mathrm{C}$ \\
\hline 3. & $\begin{array}{l}\text { Peserta didik mengamati ilustrasi } \\
\text { permasalahan yang diberikan oleh guru }\end{array}$ & 3,3 & B & 3,3 & B \\
\hline 4. & $\begin{array}{l}\text { Peserta didik memberi tanggapan } \\
\text { terhadap permasalahan yang diberikan }\end{array}$ & 2,2 & $\mathrm{C}$ & 2,9 & $\mathrm{C}$ \\
\hline 5. & $\begin{array}{l}\text { Peserta didik melakukan eksperimen } \\
\text { sesuai petunjuk LKPD yang diberikan }\end{array}$ & 2,3 & $\mathrm{C}$ & 2,6 & $\mathrm{C}$ \\
\hline 6. & $\begin{array}{l}\text { Peserta didik bekerja sama untuk saling } \\
\text { kompak dalam melakukan kegiatan } \\
\text { eksperimen }\end{array}$ & 2,3 & $\mathrm{C}$ & 2,9 & $\mathrm{C}$ \\
\hline 7. & Peserta didik mencatat hasil diskusi & 2,3 & $\mathrm{C}$ & 3,3 & $\mathrm{~B}$ \\
\hline 8. & $\begin{array}{l}\text { Peserta didik mempresentasikan hasil } \\
\text { diskusi kepada kelompok lain }\end{array}$ & 2,6 & $\mathrm{C}$ & 3,3 & B \\
\hline 9. & $\begin{array}{l}\text { Peserta didik memberikan kesimpulan } \\
\text { untuk menjawab kembali permasalahan } \\
\text { awal yang diajukan }\end{array}$ & 2,0 & $\mathrm{C}$ & 3,2 & B \\
\hline & Rata - rata & 2,4 & & $\mathbf{3 , 0}$ & \\
\hline & Kategori & & $\mathbf{C}$ & & B \\
\hline
\end{tabular}

Keterangan:

A (Baik Sekali);

B (Baik);

C (Cukup) dan

D (Kurang)

Tabel 1 tersebut menunjukkan rata-rata satuan aktivitas peserta didik per siklus cenderung mengalami peningkatan, dimana secara kuantitatif terjadi peningkatan dari siklus I rata-rata yang di peroleh sebesar 2,4 menjadi 3,0 pada siklus II dan secara kualitatif meningkat dari kategori cukup menjadi kategori baik.

Berdasarkan hasil analisis deskriptif terhadap aktivitas peserta didik persatuan aktivitas pada siklus I yang terlihat pada Tabel 1 menunjukkan bahwa rata-rata aktivitas peserta didik adalah sebesar 2.4 dengan kategori cukup (C). Satuan aktivitas peserta didik pada siklus I yang berada pada kategori cukup yaitu 1) mendengarkan dan memperhatikan guru saat membuka pelajaran; 2) merespon atau menanggapi pertanyaan dari guru; 3) memberi tanggapan terhadap permasalahan; 4) melakukan LKPD; 5) bekerja sama; 6) mencatat hasil diskusi;
7) mempresentasikan hasil diskusi dan 8) memberikan kesimpulan. Aspek ini diharapkan dapat di pertahankan dan lebih meningkat lagi pada siklus selanjutnya.

\section{Data Keterlaksanaan Model Pembelajaran Berbasis Masalah}

Data mengenai keterlaksanaan model pembelajaran berbasis masalah pada kelas VIII $_{C}$ SMP Negeri 1 Uepai selama proses pembelajaran berlangsung diambil dengan menggunakan lembar observasi keterlaksanaan model pembelajaran berbasis masalah dengan cara memberikan skor pada setiap aspek aktivitas yang dinilai sesuai dengan kriteria yang ditentukan. Data distribusi rata-rata aktivitas pendidik selama proses pembelajaran pada setiap siklus dapat dilihat pada Tabel 2. 
Tabel 2. Skor Rata-rata Keterlaksanaan Model Pembelajaran Berbasis Masalah pada Setiap Siklus

\begin{tabular}{|c|c|c|c|c|c|}
\hline \multirow[b]{2}{*}{ No. } & \multirow[b]{2}{*}{ Aktivitas yang Diamati } & \multicolumn{2}{|c|}{ Siklus I } & \multicolumn{2}{|l|}{ Siklus II } \\
\hline & & $\begin{array}{c}\text { Rata } \\
- \\
\text { rata }\end{array}$ & Kat. & Rata - rata & Kat. \\
\hline
\end{tabular}

Kegiatan Pendahuluan

\begin{tabular}{cccccc}
\hline 1. & Guru membuka pembelajaran. & 4,0 & $\mathrm{~A}$ & 4,0 & $\mathrm{~A}$ \\
\hline b) $\quad$ Guru memberikan motivasi. & 2,0 & $\mathrm{C}$ & 3,0 & $\mathrm{~B}$ \\
\hline c) & Guru memberikan apersepsi. & 2,5 & $\mathrm{C}$ & 3,0 & $\mathrm{~B}$ \\
\hline
\end{tabular}

\section{Kegiatan Inti}

\begin{tabular}{|c|c|c|c|c|c|}
\hline a) & Guru menjelaskan tujuan pembelajaran. & 2,5 & $\mathrm{C}$ & 3,0 & $\mathrm{~B}$ \\
\hline b) & $\begin{array}{l}\text { Guru menjelaskan materi pembelajaran, } \\
\text { alat serta bahan yang dibutuhkan. }\end{array}$ & 2,5 & $\mathrm{C}$ & 3,5 & $\mathrm{~B}$ \\
\hline c) & $\begin{array}{l}\text { Guru memotivasi peserta didik agar terlibat } \\
\text { dalam permasalahan yang dipilih. }\end{array}$ & 3,0 & $\mathrm{~B}$ & 3,0 & $\mathrm{~B}$ \\
\hline d) & ) Guru membagi kelompok secara heterogen. & 2,5 & $\mathrm{C}$ & 3,0 & $\mathrm{~B}$ \\
\hline e) & Guru membagikan LKPD. & 2,5 & $\mathrm{C}$ & 3,0 & $\mathrm{~B}$ \\
\hline f) & $\begin{array}{l}\text { Guru membantu peserta didik untuk } \\
\text { mendefinisikan tugas belajar yang } \\
\text { berhubungan dengan masalah. }\end{array}$ & 2,5 & $\mathrm{C}$ & 3,5 & $\mathrm{~B}$ \\
\hline g) & $\begin{array}{l}\text { Guru mendorong peserta didik untuk } \\
\text { mengumpulkan informasi yang relevan. }\end{array}$ & 2,5 & $\mathrm{C}$ & 3,0 & $\mathrm{~B}$ \\
\hline h) & $\begin{array}{l}\text { Guru membantu peserta didik } \\
\text { melaksanakan eksperimen dan } \\
\text { mendiskusikan kesimpulannya. }\end{array}$ & 3,0 & $\mathrm{~B}$ & 3,0 & $\mathrm{~B}$ \\
\hline i) & $\begin{array}{l}\text { Guru membantu peserta didik dalam } \\
\text { merencanakan dan menyiapkan hasil karya } \\
\text { seperti laporan. }\end{array}$ & 2,5 & $\mathrm{C}$ & 3,0 & $\mathrm{~B}$ \\
\hline j) & $\begin{array}{l}\text { Guru meminta perwakilan kelompok untuk } \\
\text { mempresentasikan hasil diskusinya dan } \\
\text { kelompok lain memberikan tanggapan. }\end{array}$ & 2,5 & $\mathrm{C}$ & 3,5 & $\mathrm{~B}$ \\
\hline k) & $\begin{array}{l}\text { Guru membantu peserta didik untuk } \\
\text { melakukan refleksi terhadap penyelidikan } \\
\text { mereka. }\end{array}$ & 3,0 & $\mathrm{~B}$ & 3,5 & $\mathrm{~B}$ \\
\hline 1) & $\begin{array}{l}\text { Guru memberikan penghargaan kepada } \\
\text { kelompok yang kinerjanya bagus. }\end{array}$ & 2,0 & $\mathrm{C}$ & 2,5 & $\mathrm{C}$ \\
\hline & $\begin{array}{l}\text { Guru membimbing peserta didik untuk } \\
\text { menjawab permasalahan sebelumnya. }\end{array}$ & 2,5 & $\mathrm{C}$ & 3,0 & $\mathrm{~B}$ \\
\hline
\end{tabular}




\begin{tabular}{|c|c|c|c|c|c|c|}
\hline \multirow{6}{*}{3.} & \multicolumn{6}{|c|}{ Kegiatan Penutup } \\
\hline & & $\begin{array}{l}\text { Guru meriview kegiatan hasil } \\
\text { pembelajaran. }\end{array}$ & 2,5 & $\mathrm{C}$ & 3,5 & $\mathrm{~B}$ \\
\hline & & $\begin{array}{l}\text { Guru membimbimbing peserta didik dalam } \\
\text { memberikan kesimpulan. }\end{array}$ & 3,0 & $\mathrm{~B}$ & 3,0 & B \\
\hline & & Guru memberikan evaluasi. & 3,0 & B & 3,5 & $\mathrm{~B}$ \\
\hline & & Guru memberikan tugas rumah. & 3,0 & $\mathrm{~B}$ & 3,5 & B \\
\hline & e) & Guru memberitahukan materi selanjutnya. & 3,0 & $\mathrm{~B}$ & 3,0 & B \\
\hline \multirow{7}{*}{4.} & \multicolumn{6}{|c|}{ Suasana Kelas } \\
\hline & & Peserta didik antusias. & 2.0 & $\mathrm{C}$ & 3,5 & B \\
\hline & & Guru antusias & 3,0 & $\mathrm{~B}$ & 3,0 & B \\
\hline & & Waktu sesuai alokasi waktu & 1,5 & $\mathrm{D}$ & 3,0 & B \\
\hline & & KBM sesuai skenario pada RPP & 2,0 & $\mathrm{C}$ & 3,5 & B \\
\hline & & Rata-rata & 2,6 & & 3,2 & \\
\hline & & Kategori & & $\mathbf{C}$ & & B \\
\hline
\end{tabular}

Keterangan:
A (Baik Sekali);
B (Baik);
C (Cukup) dan
D (Kurang)

Tabel 2 menunjukkan bahwa pencapaian skor aktivitas pendidik pada siklus I sebesar 2,6 yang berada pada kategori cukup dan pencapaian skor aktivitas pendidik pada siklus II sebesar 3,2 yang berada pada kategori baik. Hal ini menunjukkan bahwa terjadi peningkatan skor rata-rata aktivitas pendidik pada siklus I ke siklus II sebesar 0,6.

Keterlaksaan model pembelajaran berbasis masalah selama kegiatan belajar mengajar sebagaimana terlihat pada Tabel 2 yang terlaksana belum maksimal diantaranya yaitu: 1) pendidik kurang memberikan motivasi untuk bertanya dan menjawab; 2) pendidik kurang memberikan pengargaan terhadap kelompok yang kinerjanya bagus; 3) antusias pendidik masih kurang; 4) alokasi waktu tidak sesuai dengan rencana pelaksana pembelajaran (RPP) dan 5) kegiatan belajar mengajar $(\mathrm{KBM})$ belum sesuai scenario rencana pelaksana pembelajaran RPP.Untuk mengatasi permasalahan tersebut guru bersama peneliti melakukan analisis dan refleksi terhadap faktorfaktor yang menyebabkan kurangnya intensitas beberapa aktivitas peserta didik maupun aktivitas pendidik dalam mengelola model pembelajaran berbasis masalah pada materi Cahaya dan Alat Optik adanya beberapa kelemahan atau kekurangan pendidik diantaranya 1) pendidik kurang menyiapkan peserta didik; 2) pendidik kurang memberikan motivasi kepada peserta didik untuk menanggapi atau merespon pertanyaan dari guru, kurang memberikan motivasi dalam menyampaikan tujuan pembelajaran dan pendidik kurang memotivasi peserta didik sehingga peserta didik kurang berani dalam memberikan tanggapan terhadap permasalahan yang di berikan; 3) pendidik kurang melakukan bimbingan secara menyeruh 
terhadap semua kelompok; 4) pendidik kurang jelas dan terlalu cepat dalam menyampaikan materi sehingga peserta didik tidak mendengar apa yang di sampaikan; 5) pendidik kurang memberikan penghargaan kepada kelompok yang kinerjanya bagus dan 6) pendidik kurang melibatkan semua peserta didik untuk menyimpulkan hasil belajar. Namun, pendidik juga harus memperhatikan hal-hal yang harus dipertahankan pada siklus selanjutnya, seperti aktivitas pendidik membuka pelajaran.

Selanjutnya dengan hasil refleksi tersebut kemudian di tentukan langkah-langkah perbaikan untuk siklus II diantaranya 1) pendidik sebaiknya mempersiapkan peserta didik sebelum memulai pelajaran; 2) pendidik sebaiknya lebih memotivasi kepada peserta didik agar berani mengeluarkan pendapatnya; 3) pendidik sebaiknya melakukan bimbingan secara merata ke semua kelompok; 4) pendidik sebaiknya menyampaikan materi lebih jelas dan tidak terlalu cepat; 5) pendidik sebaiknya memberikan penghargaan kepada kelompok yang kinerjanya bagus sehingga peserta didik termotivasi dalam mempresentasikan hasil kerja LKPD dan 6) pendidik sebaiknya melibatkan semua peserta didik dalam menyimpulkan hasil pembelajaran.
Berdasarkan hasil analisis dan refleksi tersebut, pendidik melakukan perbaikan-perbaikan dalam mengajar materi pokok Cahaya dan Alat Optik sub pokok materi pembentukan bayangan pada lensa dan indra penglihatan pada manusia serta alat optik dalam kehidupan sehari-hari sesuai dengan langkah-langkah model pembelajaran berbasis masalah untuk diterapkan pada siklus II serta memperbaharui cara menyampaikan materi pembelajaran dengan selalu melibatkan peserta didik dalam pembelajaran, sehingga diharapkan dengan pembelajaran tersebut peserta didik dapat lebih aktif dalam pembelajaran sehingga tujuan pembelajaran dapat tercapai.

\section{Data Hasil Belajar Peserta Didik}

Data hasil belajar peserta didik diperoleh dengan menggunakan tes hasil belajar. Analisis data yang digunakan dalam penelitian ini yaitu analisis deskriptif terhadap hasil belajar peserta didik pada materi Cahaya dan Alat Optik. Data hasil belajar ditunjukkan dalam bentuk tes siklus yang terdiri dari tes siklus I dan tes siklus II dapat dilihat pada Tabel 3

Table 3 Deskripsi Hasil Belajar Siswa

\begin{tabular}{lcc}
\hline \multicolumn{1}{c}{ Deskripsi Hasil Belajar } & Siklus I & Siklus II \\
\hline Nilai Tertinggi & 100 & 95,5 \\
\hline Nilai Terendah & 27,3 & 55 \\
\hline Rata-rata & 70,5 & 76,1 \\
\hline Standar Deviasi & 15,4 & 10,1 \\
\hline Jumlah Tuntas & 20 & 25 \\
\hline Jumlah Belum Tuntas & 6 & 5 \\
\hline \% Ketercapaian Tuntas & 76,9 & 83,3 \\
\hline \% Kegagalan Belum Tuntas & 23,1 & 16,7 \\
\hline
\end{tabular}

Tabel 3 terlihat adanya peningkatan rata-rata hasil belajar peserta didik dari siklus I yaitu 70,5 ke siklus II yaitu76,1 dan ketuntasan belajar peserta didik meningkat dari $76,9 \%$ ke $83,3 \%$.

\section{PEMBAHASAN}

Pelaksanaan penelitian tidakan kelas dengan menggunakan model pembelajaran berbasis masalah pada materi Cahaya dan Alat Optik terdiri dari empat pertemuan yang dibagi menjadi dua siklus. Masing-masing siklus terdiri dari dua pertemuan. Pelaksanaan pembelajaran pada tiap pertemuannya terdapat kegiatan yang mencerminkan model pembelajaran berbasis masalah antara lain memberikan orientasi permasalahan, mengorganisasikan peserta didik untuk meneliti, membantu menyelidiki secara mandiri atau kelompok, mengembangkan dan mempresentasikan hasil kerja serta menganalisis dan mengevaluasi masalah. Seluruh tahapan pelaksanaan pembelajaran ini bertujuan untuk meningkatkan aktivitas dan hasil belajar peserta didik. Secara umum, hasil belajar peserta didik kelas VIII $_{C}$ yang diajar dengan menerapkan model pembelajaran berbasis masalah pada materi Cahaya dan Alat Optik mengalami peningkatan. Selain itu keterlaksanaan model pembelajaran berbasis masalah juga mengalami peningkatan sehingga antusia peserta didik juga mengalami peningkatan dari siklus I ke siklus II. 


\section{Aktivitas Peserta Didik dan Keterlaksanaan Model Pembelajaran Berbasis Masalah}

Berdasarkan rumusan masalah pertama tentang bagaimana peningkatan aktivitas belajar peserta didik kelas VIII $_{C}$ SMP Negeri 1 Uepai yang diajar dengan menggunakan model pembelajaran berbasis masalah pada materi Cahaya dan Alat Optik dapat dijelaskan berdasarkan hasil pengamatan pada siklus I dan siklus II yang cenderung mengalami peningkatan. Aspek-aspek yang masih kurang pada siklus I secara keseluruhan meningkat. Sebagaimana terlihat pada Tabel 4.1 skor rata-rata aktivitas belajar peserta didik pada siklus I yaitu 2,4 dengan kategori cukup (C) meningkat pada siklus II yaitu 3,0 dengan kategori baik (B). Penyebab rendahnya rata-rata aktivitas peserta didik pada siklus I disebabkan oleh peserta didik terbiasa cerita dalam kelas saat guru membuka pembelajaran serta pendidik yang belum menguasai kelas, peserta didik belum bisa merangkai kalimat, memiliki keberanian dan percaya diri untuk mengemukakan pendapat atau memberi sanggahan, peserta didik tidak serius mengerjakan LKPD sehingga yang bekerja dalam kelompok tidak semua berpartisipasi, peserta didik belum memahami materi pelajaran sehingga kesulitan memberikan kesimpulan untuk menjawab permasalahan awal yang diajukan terkait materi pada siklus I serta peserta didik juga baru beradaptasi dengan penelitian dan model pembelajaran berbasis masalah yang diterapkan. Sementara beberapa aktivitas peserta didik yang tergolong baik yaitu peserta didik mengamati ilustrasi permasalahan yang diberikan oleh guru. Aktivitas ini tergolong baik disebabkan karena kegiatan mengamati ilustrasi permasalahan yang diberikan oleh pendidik merupakan hal yang baru bagi peserta didik, sehingga peserta didik antusias dalam mengamati ilustrasi yang diberikan oleh pendidik. Peningkatan rata-rata aktivitas peserta didik pada siklus II menandakan bahwa kekurangan atau kelemahan yang terdapat pada siklus I dapat teratasi. Peningkatan ini disebabkan oleh peserta didik yang mulai terbiasa dengan model pembelajaran berbasis masalah, peserta didik tidak ragu dan malu mengemukakan pendapatnya, dan peserta didik juga sudah bisa beradaptasi dengan peneliti selaku pendidik baru untuk mereka.

Selain itu, keterlaksanaan model pembelajaran berbasis masalah juga meningkat dari siklus I ke siklus II dimana semua aspek yang kurang pada siklus I secara keseluruhan meningkat pada siklus II. Dimana rata-rata keterlaksanaan model pembelajaran pada siklus I yaitu 2,6 dengan kategori cukup (C) meningkat pada siklus II yaitu 3,2 dengan kategori baik (B). Kurangnya keterlaksaan model pembelajaran berbasis masalah pada siklus I disebabkan oleh pendidik yang kurang menguasai rencana pelaksana pembelajaran (RPP) dengan baik, kurang memahami karakteristik peserta didik, belum mempersiapkan mental secara maksimal serta pendidik belum beradaptasi dengan peserta didik. Keterlaksanaan model yang terlaksana dengan maksimal yaitu membuka pembelajaran. Aktivitas ini terlaksana dengan sangat baik yaitu karena hanya terdapat tiga komponen yang dinilai diantaranya mengucapkan salam, menanyakan kondisi dan memeriksa kehadiran siswa. Keterlaksanaan model pembelajaran berbasis masalah meningkat pada siklus II yaitu karena pendidik yang memperbaiki cara mengajarnya seperti memberikan motivasi dan penguatan yang lebih kepada setiap peserta didik yang aktif maupun kurang aktif, mempersiapkan mental secara maksimal untuk mengajar peserta didik yang memiliki karakter berbeda-beda, menyesuaikan waktu pembelajaran dan pembelajaran telah sesuai dengan rencana pelaksanaan pembelajaran.

\section{Hasil Belajar}

Rendahnya aktivitas peserta didik dan keterlaksaan model pembelajaran berbasis masalah oleh pendidik tersebut berdampak pada rumusan masalah yang kedua dan ketiga yaitu hasil belajar peserta didik dan ketuntasan hasil belajar peserta didik. Dimana berdasarkan hasil analisis deskriptif terhadap hasil belajar peserta didik pada materi Cahaya dan Alat Optik meningkat dari siklus I ke siklus II dengan sub pokok materi pokok sifat-sifat cahaya dan pembentukkan bayangan pada cermin untuk siklus I diperoleh rata-rata hasil belajar peserta didik sebesar 70,5. Terdapat 20 orang peserta didik atau 76,9\% yang memenuhi KKM dan 6 orang peserta didik atau $23,1 \%$ yang tidak memenuhi KKM serta yang tidak mengikuti tes siklus ini yaitu 6 orang. Hal ini berarti bahwa keberhasilan tindakan pada siklus I sudah tercapai dari kriteria keberhasilan tindakan yang sudah ditetapkan yaitu $75 \%$ dari 32 orang peserta didik. Namun keberhasilan tindakan pada siklus I hanya 1,9\%. Sementara untuk siklus II dengan nilai rata-rata sebesar 76,06 dengan jumlah yang tuntas 25 orang atau $83,3 \%$ peserta didik dan yang belum tuntas 5 orang atau $16,67 \%$ peserta didik serta yang tidak mengikuti tes siklus II sebanyak 2 orang. Hasil ini telah memenuhi ketuntasan belajar secara klasikal yaitu $75 \%$. Selain itu berdasarkan hasil analisis 
deskriptif standar deviasi siklus II lebih kecil dibanding dengan siklus I. Dapat dikatakan bahwa tingkat kesalahan peserta didik dalam mengerjakan soal pada siklus II lebih sedikit dibandingkan siklus I. Rendahnya hasil keberhasilan tindakan pada siklus I disebabkan oleh kemampuan peserta didik yang berbeda-beda, mengingat istilah-istilah dalam fisika masih kurang, kurang memahami materi yang diajarkan serta kurang mahir dalam pengoperasian matematika. Peningkatan hasil belajar pada siklus II disebabkan oleh peserta didik yang mulai terbiasa dengan model pembelajaran berbasis masalah sebagaimana karakteristik dari model pembelajaran berbasis masalah sendiri yang dapat mengembangkan kemampuan peserta didik untuk membangun pengetahuan mereka melalui penyajian pembelajaran yang berdasarkan pada masalah nyata peserta didik sehingga pengetahuan mereka dapat diterima oleh peserta didik.

Peningkatan hasil belajar ini ditunjukkan dengan adanya peningkatan aktivitas belajar peserta didik dari siklus I ke siklus II. Peningkatan ini juga mengindikasikan bahwa pendidik sudah dapat mengelolah pembelajaran dengan menerapkan model pembelajaran berbasis masalah dengan baik dilihat dari peserta didik yang telah mencapai ketuntasan belajar minimal secara individu dan klasikal seperti dipersyaratkan oleh kurikulum 2013, walaupun masih ada beberapa peserta didik yang belum mencapai ketuntasan belajar disebabkan oleh kurangnya peserta didik memahami materi pelajaran dengan baik, operasi matematika peserta didik yang masih kurang serta kurang motivasi pentingnya sekolah dari orang tua sehingga ada beberapa peserta didik yang malas kesekolah.

Keberhasilan penerapan model pembelajaran berbasis masalah (PBL) dalam pembelajaran IPA dapat dilihat dalam penelitian Normayanti (2017) yaitu ketuntasan belajar peserta didik kelas $\mathrm{X} \mathrm{IPA}_{1}$ SMA Negeri 4 Konawe Selatan yang diajar dengan model pembelajaran berbasis masalah pada setiap siklus cenderung mengalami peningkatan, dimana pada siklus I persentase ketuntasan belajar peserta didik sebesar $42,1 \%$ dan pada siklus II yaitu $94,7 \%$ sementara Indah Wulandari (2017) yaitu adanya peningkatan hasil belajar siswa yang diajar dengan model pembelajaran berbasis masalah (PBL) pada materi Alat-Alat Optik di MTsN Rukoh Banda Aceh, dan Rian Ari Utomo (2015) yaitu ada peningkatan kemampuan kognitif Fisika siswa sebesar $40 \%$ pada kelas X IPA 3 SMA Negeri 1 Cawas Klaten dengan penerapan model pembelajaran berbasis masalah dilengkapi prezi.
Dengan demikian, dapat dikatakan bahwa penerapan model pembelajaran berbasis masalah sebagai alternatf pilihan dalam meningkatkan hasil belajar peserta didik kelas VIII $_{C}$ SMP Negeri 1 Uepai telah mencapai Ketuntasan Kriteria Minimum (KKM) dalam pembelajaran fisika khususnya pada materi Cahaya dan Alat Optik.

\section{KESIMPULAN}

Aktivitas peserta didik kelas VIII $_{C}$ SMP Negeri 1 Uepai yang diajar dengan model pembelajaran berbasis masalah diperoleh skor rata-rata pada siklus I sebesar 2,4 dengan kategori cukup (C) dan meningkat pada siklus II sebesar 3 dengan kategori baik (B) meningkat sebesar 0,6. Hasil belajar peserta didik kelas VIII $_{C}$ SMP Negeri 1 Uepai yang diajar dengan model pembelajaran berbasis masalah diperoleh pada siklus I, nilai terendah 27,3 dan nilai tertinggi 100 dengan skor rata-rata sebesar 70,45 dan standar deviasi 15,4 sementara pada siklus II diperoleh nilai terendah 55 dan nilai tertinggi 95 dengan skor rata-rata 76,06 dan standar deviasi 10,1 . Ketuntasan belajar peserta didik kelas VIII $_{C}$ SMP Negeri 1 Uepai yang diajar dengan model pembelajaran berbasis masalah pada setiap siklus cenderung mengalami peningkatan, dari $76,9 \%$ pada siklus I menjadi 83,33\% pada siklus II.

\section{DAFTAR PUSTAKA}

Agusnanto. 2013. Penerapan Model Pembelajaran Quantum Learning dan Model Pembelajaran Problem Based Learning untuk Meningkatkan Hasil Belajar Siswa pada Mata Pelajaran Diklat Programmable Logic Controller di SMK Muhammadiyah 3 Yogyakartan. Yogyakarta: Universitas Negeri Yogyakarta.

Aqib, Z. 2013. Model-Model, Media dan Strategi Pembelajaran Kontekstual (Inovatif). Bandung: Yrama Widya.

Arikunto, S. 2008. Dasar-asar Evaluasi Pendidikan Edisi Revisi. Jakarta: Bumi Aksara.

Arsyad, A. 2016. Media Pembelajaran. Jakarta: Raja Grafindo Persada.

Kementrian Pendidikan dan Kebudayaan Republik Indonesia. 2017. Buku Guru Ilmu Pengetahuan Alam SMP/MTs Kelas VIII. Jakarta.

Lestari, N. S. 2007. Pengaruh Pembelajaran Berbasis Masalah (Problem-Based Learning) dan Motivasi Belajar terhadap Prestasi Belajar Fisika bagi Siswa Kelas VII SMP. Bali: Universitas Pendidikan Ganesha Singaraja. 
Mulyasa. 2016. Revolusi dan Inovasi Pembelajaran. Bandung: PT Remaja Rosdakarya.

Ramly. 2006. Metodologi Penelitian Pendidikan. Kendari: Universitas Halu Oleo

Sudjana. 2002. Metoda Statistika. Bandung: Transito.

Sugiyanto. 2010. Model-model Pembelajaran Inovatif. Surakarta: Yuma Pustaka

Sugiyono. 2013. Metode Penelitian Kuantitatif, Kualitatif dan $R \& D$. Bandung: Alfabeta.

Fitriani, N. R. 2015. Pengaruh Model Pembelajaran Problem Based Learning (PBL) terhadap Keterampilan Tingkat Tinggi Peserta Didik pada Materi Alat-alat Optik Kelas X SMA Muhammadiyah 7 Yogyakarta.Yogyakarta: UIN Sunan Kalijaga.

Gusnawati. 2018. Penerapan Model Discovery Learning untuk Meningkatkan Keterampilan Proses Sains dan Hasil Belajar IPA Ranah Kognitif Peserta Didik Kelas VIIb SMPN 1 Sawerigadi pada Materi Pokok kalor dan Perpindahannya. Kendari: Universitas Halu Oleo.

Normayanti. 2017. Penerapan Model Pembelajaran Berbasis Masalah untuk Meningkatkan Aktivitas dan Hasil Belajar Ranah Kognitif Siswa pada Materi Fluida Statis Kelas X IPA Sma Negeri 4 Konawe Selatan. Kendari: Universitas Halu Oleh

Nurhadi. 2003. Pembelajaran Kontekstual ( Constekstual Teaching \& Learning). Malang: Universitas Negeri Malang.

Pramestasari, M. D. 2012. Efektifitas Penggunaan Model Pembelajaran Berbasis Masalah (Problem Based Learning-PBL) terhadap Hasil Belajar Ipa Siswa Kelas V di SD Gugus Hasanudin Salatiga Semester II Tahun Ajaran 2011/2012. Salatiga: Universitas Kristen Satya Wacana

Pratiwi, D. A. 2010. Pembelajaran Berbasis Masalah (Problem Based Learning) dengan Metode Proyek dan Resitasi Ditinjau dari Kreativitas dan Konsep Diri (Self Concept) Siswa. Surakarta: Universitas Sebelas Maret

Putri, M. D. 2014. Pengaruh Penerapan Model Pembelajaran Berbasis Masalah (Problem Based Learning) terhadap Hasil Belajar Fisika dan Sikap Ilmiah Siswa di SMPN 11 Kota Bengkulu. Universitas Bengkulu
Setyowati. 2007. Pengaruh Motivasi Belajar terhadap Hasil Belajar Siswa Kelas VII SMPN 13 Semarang. Semarang: Universitas Negeri Semarang

Sudarman. 2007. Problem Based Learning Suatu Model Pembelajaran untuk Mengembangkan dan Meningkatkan Kemampuan Memecahkan Masalah. Samarinda: Universitas Mulawarman.

Utomo, R. A. 2015. Penerapan Model Pembelajaran Berbasis Masalah Menggunakan Prezi untuk Meningkatkan Kemampuan Belajar Kognitif Siswa Kelas X 3 SMA Negeri 1 Cawas Klaten Tahun Pelajaran 2015/2015. Surakarta: Universitas Sebelas Maret

Wahyuningsih, L. E. 2016. Hubungan antara Aktivitas Belajar Siswa dengan Hasil Belajar pada Pelajaran Ekonomi Materi Akuntansi Siswa Kelas XI IPS SMA Negeri 7 Banda Lampung Tahun Pelajaran 2015/2016. Bandar Lampung: Universitas Lampung.

Zahro, U. R. 2016. Pengaruh Model Problem Based Learning Berbasis Science Edutaiment terhadap Kemampuan Berpikir Kritis Siswa SMP. Semarang: Universitas Negeri Semarang

Firmansyah, A., Kosim dan Syahrial A. 2015. Pengaruh Pembelajaran Berbasis Masalah dengan Metode Eksperimen pada Materi Cahaya terhadap Hasil Belajar Fisika Kelas VIII SMPN 2 Gunungsari Tahun Ajaran 2014/2015.Mataram: Universitas Mataram. Volume 1 Nomor 3.

Wirda, A. G. H, dan Ibnu K. 2015. Penerapan Pembelajaran Model Problem Based Learning $(P B L)$ untuk Meningkatkan Keterampilan Proses Sains dan Motivasi Belajar Siswa pada Materi Alat-alat Optik. Universitas Syiah Kuala Banda Aceh. Volume 3 Nomor 2.

Wulandari I., Ida M., dan Fera A. 2017. Penerapan Pembelajaran Berbasis Masalag (PBL) untuk Meningkatkan Hasil Belajar Materi Cahaya dan Alat Optik pada Siswa Kelas VIII MTsN Rukoh Banda Aceh. ISBN 978-602-50939$0-6$. 